\title{
Questions of Ethics: How Family Planning Changed Under Indira Gandhi's Emergency
}

\section{Hannah Johnson}

The Indian Emergency years of 1975-1977 were a period in which Indira Gandhi ruled with an iron fist. Family planning laws were something that was not new to India during this complicated period, however. The history of population issues in India is longer than the country's independence, so why is this particular era remembered specifically for its family planning initiatives? The ways in which the policies that were created during this period were more aggressive, unethical, and debatable will be examined in this paper. The first section will look at a brief history of family planning in India in order to be able to compare it to that of the Emergency. The next section will examine the methods used to get Indian people to participate in the family planning drives and efforts - specifically the unethical methods used on lower caste Indians. The following section will observe the influence that Indira Gandhi's son Sanjay Gandhi had on the movement and arguably crafted it into what we know it as today. The final section will look at the idea that family planning efforts completely took over everyday life for Indians, and the idea that one could not escape sterilization. As previously stated, family planning initiatives were by no means new to India during the Emergency under Indira Gandhi; we can however argue that the drives that occurred during this period were the most aggressive through unethical practices and controversial means, created by the central government.

In order to fully understand the changes that occurred during the Emergency in India it is important to first understand the background of family planning policy since Indian independence. Given the scope of this paper, the information discussed is somewhat general and discusses India as a whole. What seemed to shock many people, including independent India's 
first Prime Minister, Jawaharlal Nehru, was that India's population continued to boom after independence, despite the years of war and famine in the nation. ${ }^{1}$ Over twenty years before the Emergency, India's family planning efforts began very slowly through India's Congress party and Jawaharlal Nehru. During the 1950s Nehru argued that economic development would be enough to combat extreme population growth, but it was not clear how he planned on achieving this development. ${ }^{2}$ American advisors at the time advised Nehru to think about India's development in the opposite sense. They believed that stopping extreme population growth would lead to economic development. ${ }^{3}$ Although this was advised, it took years for the Indian government to come to terms with such a plan. Nehru agreed with birth control, but he did not believe that it could "cure" poverty. ${ }^{4}$ During the 1950 s, India became the first nation in the world to have an official program to reduce fertility, yet it still remained fairly low in Nehru's priorities. ${ }^{5}$ While family planning was not a priority for Nehru's government there was still some movement during this period. The 1950s marked the beginning of a series of five-year plans produced by the National Planning Commission which would continue into Indira Gandhi's time as Prime Minister, plans produced by the National Planning Commission. This first five year program would be funded by only $0.03 \%$ of the Indian budget for development, which was initially meant to produce surveys, open clinics and educate people about birth control through the rhythm method. ${ }^{6}$ There were no targets at this point, showing again that family planning initiatives were not a priority for Nehru's government at the time. Most of his development

\footnotetext{
${ }^{1}$ Matthew Connelly, "Population Control in India: Prologue to the Emergency Period, " Population and Development Review, 32 (2006): 632.

${ }^{2}$ Rebecca J. Williams, "Storming the Citadels of Poverty: Family Planning under the Emergency in India, 19751977" The Journal of Asian Studies, 73(2014): 480.

${ }^{3}$ Ibid.

${ }^{4}$ Connelly, "Population Control," 632.

5 James Chadney, "Family Planning: India's Achilles Heel," Journal of Asian and African Studies, 22 (1987): 220.

${ }^{6}$ Ibid.
} 
budget was going towards industrializing India and developing rural areas. ${ }^{7}$ The Family Planning commission began another five-year plan just after the previous one was completed; this plan included targets of clinic building and also the beginning of free contraception. Unfortunately most of the clinics that had been created since Independence were overpopulated and underfunded therefore the idea of sterilization being the only real long term option appeared. ${ }^{8}$ For example, beginning in 1957 Madras became the first state to subsidize sterilizations. ${ }^{9}$

Nehru now believed that he needed to instill the idea of family planning into Indian society so that it would be something that they did not need to think twice about. ${ }^{10}$ In 1960 , family planning became much more important to Nehru's government. We can speculate that this is due to the lack of economic development through other means. Nehru increased the funding for family planning and attempted to increase the number of clinics, but unfortunately there were concerns about low participation in clinics. ${ }^{11}$ In order to attempt to change this, towns and cities were instructed to start their own family planning committees. During this period, the government also created the opportunity for family planning advice to be available in private dwellings. ${ }^{12}$ The Indian government continued to give Indians many family planning options, including mobile sterilization units for those who were unable to access a clinic or hospitals. In $1962,158,000$ people were sterilized, many in these mobile units. ${ }^{13}$

The government's involvement with family planning increased during this period; in 1965, an official commissioner of family planning was appointed at a national level. ${ }^{14}$ Different forms of birth control were also appearing alongside sterilization. The intrauterine device (IUD)

\footnotetext{
${ }^{7}$ Connelly, "Population Control," 641.

${ }^{8}$ Ibid., 642.

${ }^{9}$ Chadney, "Family Planning", 221.

${ }^{10}$ Williams, "Storming the Citadels of Poverty," 483.

${ }^{11}$ Connelly, "Population Control," 645.

12 Ibid. \& Chadney, "Family Planning”, 221.

${ }^{13}$ Connelly, "Population Control," 645.

${ }^{14}$ Chadney, "Family Planning," 222.
} 
was introduced into India in 1965 with an initially high success rate; approximately 29 million women accepted IUDs between 1965 and 1967. ${ }^{15}$ Although the IUD had initial success it is unclear why it was not as successful in future campaigns, perhaps due to the lack of education about IUD according to Connelly. ${ }^{16}$ Despite the family planning initiatives that began prior to Indira Gandhi's time as Prime Minister, India was still relying heavily on outside food sources to feed its growing population. ${ }^{17}$ The health ministry tried again to make a change in the population by offering to provide the funds to create monetary incentives; however the states were given funding in lump sums so it is unclear how the payments were distributed. ${ }^{18}$ This new emphasis appeared to be connected with Indira Gandhi's rise to power as the Prime Minister; the Congress party had a newfound political commitment to family planning. Gandhi appeared to understand the importance of family planning on economic growth, although it was not an official political objective with targets until $1975 .{ }^{19}$

Birth control options were becoming increasingly common in India and an example of this is the postpartum program, which began in 1969. This program gave women the opportunity to gain access to birth control while they were at the hospital either giving birth or to get an abortion. ${ }^{20}$ A few years following this, the government passed the Medical Termination of Pregnancy Act, making abortions legal for health reasons or contraceptive failure. ${ }^{21}$ During the period just prior to the Emergency (1971-1973), sterilization campaigns began in certain states with monetary incentives, as well as disincentives. ${ }^{22}$ Although these initiatives were in place

\footnotetext{
${ }^{15}$ Connelly, "Population Control," 630.

${ }^{16}$ Ibid., 657.

${ }^{17}$ Ibid., 652.

${ }^{18}$ Ibid., 656.

${ }^{19}$ Davidson R. Gwatkin, "Political Will and Family Planning: The Implications of India's Emergency Experience," Population and Development Review, 5 (1979): 35.

${ }^{20}$ Chadney, "Family Planning", 223.

${ }^{21}$ Ibid.

${ }^{22}$ Gwatkin, "Political Will and Family Planning," 33.
} 
before the Emergency, we will discuss in the following section the aggressiveness with which these programs were enforced in between 1975-1977. With this background, we must now attempt to understand the difference between the aforementioned periods and the Emergency period.

In order to fully understand the Emergency period's family planning initiatives we must look at the methods used to attempt to decrease India's birth rate. Although the methods used by the Indian government during the Emergency were not new, they were used during this period in a much more aggressive and unethical manner. The Emergency was a strict political move that Indira Gandhi made after being asked to resign in 1975; the move included censorship, the arrest of the opposition and attempted economic development plans. Gandhi created a twenty point plan for economic and social development only four days after declaring Emergency rule. ${ }^{23}$ Some of these points included income tax relief for the middle class, controlled prices for essential supplies, as well as irrigation programs. ${ }^{24}$ It is interesting to note that this plan did not include family planning at all, which is when Gandhi's son Sanjay Gandhi became a more important political figure. Sanjay created a five point program, just after the twenty point program was announced, in which he discussed family planning as the most important issue in India. This specific program will be discussed further in the following section.

In 1976, the Central Ministry of Health and Family Planning made a statement that it wanted to "transform India from a soft state to a nation with strong dedication to reduce the rate of population growth". ${ }^{25}$ Karan Singh, the Minister of Health and Family Planning at the time of the Emergency, announced the official targets of family planning in the National Population

\footnotetext{
${ }^{23}$ Pupul Jayakar, Indira Gandhi: An Intimate Biography, (New York: Pantheon Books, 1992),213.

${ }^{24}$ Jayakar, "Indira Gandhi," 213-214.

${ }^{25}$ Ibid.
} 
Policy. ${ }^{26}$ This policy aimed to reduce poverty, raise the marriage age, increase female literacy, and increase compensation for sterilization. ${ }^{27}$ Singh also gave control to the state governments when it came to family planning laws and meeting quotas, allowing them to decide the severity of the laws. Despite this, there was still a lack of method for the implementation besides mass sterilization. ${ }^{28}$ There was also some mention of compulsory sterilization, although this never came to be an official law.

Measures used during this period were much harsher and more aggressive than those used in the past; which is evident through the effect they had on average Indians. We can argue that this became the period not only of sterilization, but of the sterilization certificate. The policies created by all levels of government were based around the significance of this certificate. During the Emergency rule, laws were created to help the family planning drives reach their full potential. Government officials were told to do whatever they needed to in order to reach these goals, however unethical their means. Government employees were given quotas they needed to fill by motivating and encouraging people to be sterilized. ${ }^{29}$ These regulations were very strict and those who did not meet quotas found themselves in danger. In 1976, government employees were told that they were not allowed to have three or more children or their benefits, which included maternity leave and allowances, would be revoked. ${ }^{30}$ The only way to restore these was to present a sterilization certificate. ${ }^{31}$ The benefits were mainly divided into positive incentives and negative incentives. Although these incentives varied by state, most were similar. Government employees were given raises if they were sterilized and punished if they were not. ${ }^{32}$

\footnotetext{
${ }^{26}$ Williams, "Storming the Citadels of Poverty," 473.

${ }^{27}$ Chadney, "Family Planning," 225.

${ }^{28}$ Ibid., 225.

${ }^{29}$ Williams, "Storming the Citadels of Poverty," 473.

${ }^{30}$ Ibid., 486.

${ }^{31}$ Ibid.

${ }^{32}$ Chadney, "Family Planning", 225
} 
The average citizen felt the changes these policies made as well. For example, the government controlled who was given land, especially among poorer citizens; if you were not sterilized, you would not be given a plot of land. ${ }^{33}$ Similarly during this period, people who did not have a sterilization certificate were unable to access the free medical care being offered by the government. This was part of a program the government had started to encourage people to be sterilized, because it had its "perks." ${ }^{34}$ But things got more complicated, likely due to the lack of control that the central government had, when medical treatment began to only be offered free if one had a certificate. Similarly, families would be denied food rations if they had three or more children and government loans were only granted to those who were sterile and could prove it. ${ }^{35}$ There were also instances where "trick sterilization" occurred, where people going into the hospital for an operation would be unknowingly sterilized in the process; an extreme unethical practice. ${ }^{36}$ There were also cases where men were pulled off buses to be sterilized in large groups. This shows that it was nearly impossible to live a normal life during this time without being sterilized or scared for your life if you were not. ${ }^{37}$ It is interesting to note that the poor were particularly targeted by these sterilization practices through incentives that they needed such as money, education and healthcare. ${ }^{38}$

States that wanted compulsory sterilization had plans to create fines for people who had three or more children and were not sterilized, which targets poorer people who were not able to simply pay the fine if they wished to have more children. ${ }^{39}$ The government's policies were meant to target poorer people who were more likely to have larger families, be less educated

\footnotetext{
${ }^{33}$ Emma Tarlo, Unsettling Memories: Narratives of the Emergency in Delhi, (Los Angeles: University of California Press, 2003), 155.

${ }^{34}$ Ibid., 158.

${ }^{35}$ Chadney, "Family Planning", 226

${ }^{36}$ Tarlo, Unsettling Memories, 158.

${ }^{37}$ Connelly, "Population Control," 629.

${ }^{38}$ Ibid.

${ }^{39}$ Ibid.
} 
about birth control methods, more vulnerable, and more easily convinced by money. ${ }^{40}$ According to Williams, the Indian governments both at central and state levels appeared to see family planning during the Emergency as an attempt to achieve a "utopian vision of modern India free from poverty." $" 41$ This was a period in which the government wanted complete control of the population and as the sterilization program suggests, decreasing the population of lower caste Indians. ${ }^{42}$ In Tarlo's book about memories of the Emergency, she quotes a street sweeper as saying "whatever laws in India are enforced it is only the poor people who face the problems; not the rich."43 Although all the laws claimed to be applicable to all Indians, it is clear that the poor suffered more during this period. ${ }^{44}$

Compulsory sterilization never officially became law, but the idea that it was even considered as a possibility speaks to the unethical practices of this period. The idea itself had a huge impact on India and its family planning initiatives. The state of Maharashtra, for example, was one of the states whose government agreed with compulsory sterilization. The compulsory sterilization law that was drafted in this state was never rejected by the central government, but it was instead sent back for review. ${ }^{45}$ The law called for the sterilization of the male in any family with 3 or more children within 180 days of the birth of the third child. This was all to be paid for by the state government, and if unsuccessful, his partner would be given an abortion and the male re-sterilized. ${ }^{46}$ The policy would have included jail time and inevitable sterilization if people did not comply. Although this law never officially came into effect, many of the parts of it were already in effect in many states. Despite being expected to become a law before the end

\footnotetext{
${ }^{40}$ Connelly, "Population Control," 629.

${ }^{41}$ Williams, "Storming the Citadels of Poverty," 478.

${ }^{42}$ Ibid.

${ }^{43}$ Tarlo, Unsettling Memories, 152.

${ }^{44}$ Lynn C. Landman, "Birth Control in India: The Carrot and the Rod ," Family Planning Perspectives, 9 (1977): 102.

${ }^{45}$ Ibid.

${ }^{46} \mathrm{Ibid}$.
} 
of Emergency rule, the law only made it as far as the legislative assembly. ${ }^{47}$ It was seen as a sort of last resort given that no other policies were changing the population as much as sterilization through coercion. The question now becomes why not make it official? As Connelly argues this whole period was based around the theme of "overriding individual dignity and welfare for national population concerns." ${ }^{48}$ India's population in 1976 was 600 million; by the end of March 19778 million people had been sterilized across the country. ${ }^{49}$ This exceeded the number of any other country's sterilization program in a single year.

Indira Gandhi always denied her approval of coercion and claims to not agree with it at all. ${ }^{50}$ Even during the end of the Emergency, the government continued to support the idea that all sterilization was voluntary. ${ }^{51}$ There are many instances where Indians were denied something that they needed unless they had a sterilization certificate, making the campaigns far from voluntary. The programs implemented during this period were based solely on population control - the government had no interest in reproductive health or women's rights. ${ }^{52}$ India's government was doing everything in its power to ensure that as many people were sterilized as possible, especially the poor. ${ }^{53}$ The government completely ignored the possibility of other types of less permanent birth control, such as the birth control pill or IUD. ${ }^{54}$ More intense family planning occurred during this time because there was an increase in government control, allowing it to achieve what it wanted. Arguably another main reason behind the sterilization drives occurring when they did was Sanjay Gandhi. Many government officials had influence over the policies of

\footnotetext{
${ }^{47}$ Kaval Gulhati, “Complusory Sterilization: The Changes in India's Population Policy,” Science, 195 (1977): 1304.

${ }^{48}$ Connelly, "Population Control," 629.

${ }^{49}$ Landman, "Birth Control in India," 103.

${ }^{50}$ Chadney, "Family Planning," 225.

${ }^{51}$ Williams, "Storming the Citadels of Poverty," 473.

${ }^{52}$ Connelly, "Population Control," 629.

${ }^{53}$ Tarlo, Unsettling Memories, 160.

${ }^{54}$ Landman, "Birth Control in India," 102.
} 
the Emergency, but Sanjay's influence was the most enormous. The following section will discusses Sanjay's personal influence on these unethical practices.

Sanjay Gandhi had a significant impact on the increase of sterilization targets in 1976 and on setting up other policies as well. ${ }^{55}$ Sanjay, who was a member of the Youth Congress Party, created his own five point program at the beginning of the Emergency which included family planning. Although Sanjay was not a government official, he was very influential and considered this program to be a "statement of national policy," but it soon became clear that fertility was of the utmost importance to him. ${ }^{56}$ He pushed family planning to the top of the Indian government's to-do list through his personal interest. Although it is unknown why Gandhi had such a strong interest in the subject, it was the topic of many of his public addresses. ${ }^{57}$ Under Sanjay's supervision, Delhi and the Northern regions of India were the areas where Emergency family planning was most intense. ${ }^{58}$ Sterilization drives were used as a sort of political punishment in this area; if people were in disagreement with Sanjay or his mother's government they would be sterilized. ${ }^{59}$ Sanjay's influence increased the sterilization targets and also had an influence on creating policies. ${ }^{60}$ Since Delhi was where Sanjay yielded the most power, it is there that the highest percent of sterilizations occurred. He committed Delhi and the surrounding area to family planning. ${ }^{61}$ Since it was the most populated state during the Emergency, Sanjay felt pressured to achieve high numbers of sterilization. ${ }^{62}$ The whole Gandhi family had influence here, and Sanjay was therefore able to get his message across more easily and through the right government channels. This was common in most of the northern Indian states because they were all heavily

\footnotetext{
55 Gwatkin, "Political Will and Family Planning," 35.

${ }^{56}$ Chadney, "Family Planning," 225.

${ }^{57}$ Gwatkin, "Political Will and Family Planning," 35.

58 Jayakar, "Indira Gandhi," 229.

${ }^{59}$ Chadney, "Family Planning," 226

${ }^{60}$ Gwatkin, "Political Will and Family Planning," 33.

61 Ibid., 42.

62 Ibid.
} 
influenced by the Gandhi family. Conversely, the states less directly under the control of the Gandhi family felt less pressure to produce as many sterilizations. ${ }^{63}$ Sanjay's family planning promotion had a significant influence on family planning policy, and on his mother's own policies. Sanjay likely influenced his mother into seeing that family planning should be more of a priority during her time as Prime Minister. It is also interesting to note that of all Sanjay's points in his five point program, only family planning was promoted. ${ }^{64}$ It is clear that Sanjay had a huge impact on the family planning, sterilization policies and drives; one could even argue that one of the reasons that they came to be so harsh and unethical was due to his influence. Due to Sanjay's obsession with family planning, India transformed into a state in which family planning was everywhere. The following section will discuss how the country became overwhelmed with family planning initiatives and how this created unethical policies.

Now that the measures used and Sanjay Gandhi's influence on Emergency policies have both been observed, we must understand that another change made to family planning during the Emergency was the idea that all areas of Indian life were connected to it. Before the Emergency period, Indira Gandhi never made this a priority, similar to her father Prime Minister Nehru. But due to the strong influence of Sanjay Gandhi and the Emergency rule that gave power to control over any of the areas she pleased, family planning became an important theme. This section will discuss the idea that sterilization was viewed as a huge part of India's economic development, as well as how the government was able to involve itself in healthcare, education, workplaces and housing in order to insure that people were complying to aid India's development. The government was able to use all these different areas to force people to become sterilized; it was as if the sterilization certificates were a golden ticket to access the above mentioned sectors.

\footnotetext{
${ }^{63}$ Gwatkin, "Political Will and Family Planning," 43.

${ }^{64}$ Ibid., 52.
} 
After the Emergency, the term Emergency became known as a synonym for the time of sterilizations, this shows us the impact that sterilization had on average Indians. ${ }^{65}$

We see that the focus of India during this period was a renewed interest in population control. Everything had a connection with family planning during this period compared to the minimal initiatives that took place during previous governments. The government did this by removing all ethical and logical restraints and doing anything to achieve population control. The evidence suggests that the government only cared about numbers and infiltrated India's entire infrastructure to make the changes necessary. ${ }^{66}$ Tarlo discusses something called the 'sterilization net'; where everything was caught up in the sterilization movement, from work to the government establishments. ${ }^{67}$ It became dangerous for people who did not have sterilization certificates to be near these areas because of the risk of being caught not being sterilized. ${ }^{68}$ It was also dangerous because the authorities, including bosses and teachers, were encouraging people to become sterilized because the government gave them quotas to fill. They too would be at risk if they were not doing their part. ${ }^{69}$ Those who encouraged sterilization were also given incentives for promoting and educating people about sterilization. ${ }^{70}$ For example, teachers were told that they needed to tell students about the importance of family planning and the incentives that came with it, or their salaries would be withheld. ${ }^{71}$ Labourers looking to be hired were also influenced by the sterilization programs of the Emergency; many companies were encouraged by the government not to hire people unless they had a sterilization certificate. ${ }^{72}$

\footnotetext{
${ }^{65}$ Williams, "Storming the Citadels of Poverty," 471.

${ }^{66}$ Gwatkin, "Political Will and Family Planning", 52

${ }^{67}$ Tarlo, Unsettling Memories, 160.

68 Ibid.

${ }^{69}$ Ibid., 148.

${ }^{70}$ Landman, "Birth Control in India," 102.

${ }^{71}$ Gwatkin, "Political Will and Family Planning", 43.

72 Ibid.
} 
As previously mentioned, the sterilization drives also affected the food ration system, government loans, and plot handouts for housing. ${ }^{73}$ It is clear to see that India's family planning initiatives were evident in all areas of Indian life. Another example is the "freezing" of representatives in the lower government house; if their regions were able to keep up with the quotas then the representatives were kept in their positions, as a reward. ${ }^{74}$ Williams compared these family planning drives to "battlefields in war on poverty" and similar to war, family planning needed to be a national commitment. ${ }^{75}$ This is why so many sectors of Indian society were infiltrated by family planning and sterilization drives.

In conclusion, all the measures and tactics that were brought into the Emergency family planning drives were not new measures. India has had a long history of family planning efforts since Independence which continued through the Emergency era. However the tactics were used much more aggressively, to the point where Indira Gandhi was not re-elected in the following election because of the Indian people's view on the sterilization drives. Throughout independent Indian history, the idea of family planning is a constant; from Nehru's minimalistic approach through education about the rhythm method to Indira Gandhi's Emergency policies that lead led to millions of people being coerced into being sterilized. Here a condensed history of Indian family planning leading up to the Emergency has been described. The methods that led to this period being known as controversial give some insight into the severity of this period's initiatives. Leading up to the Emergency, sterilization and birth control were being used as forms of population control given voluntarily to the Indian population. This issue really came to light with Sanjay Gandhi's personal interest in family planning and population control. Sanjay was an important figure in the sterilization drives and his efforts were evident all over India, especially

\footnotetext{
${ }^{73}$ Chadney, "Family Planning," 225.

${ }^{74}$ Landman, "Birth Control in India," 102.

${ }^{75}$ Williams, "Storming the Citadels of Poverty," 484.
} 
in the northern regions. The idea that all areas of Indian society were affected by the Emergency family planning initiatives was made clear through the Emergency legislation. All areas of Indian society were affected in order to attempt to guarantee that people were supporting the family planning initiatives. Work, school and daily life were all affected specifically by the sterilization drives. It is evident through these examples that India during the Emergency had very similar family planning efforts to those of previous governments, but the efforts of the Emergency were undoubtedly more aggressive and unethical in nature. 


\section{Bibliography}

Chadney, James. "Family Planning: India's Achilles Heel." Journal of Asian and African Studies, 1987: 218-231.

Clibbens, Patrick. "The Destiny of this City is to be the Spiritual Workshop of the Nation: Clearing Cities and Making Citizens during the Indian Emergency." Contemporary South Asia, 2014: 51-66.

Connelly, Matthew. "Population Control in India: Prologue to the Emergency Period ." Population and Development Review, 2006: 629-667.

Gulhati, Kaval. "Complusory Sterilization: The Changes in India's Population Policy." Science, 1977: 1300-1305.

Gwatkin, Davidson R. "Political Will and Family Planning: The Implications of India's Emergency Experience." Population and Development Review, 1979: 29-59.

Jayakar, Pupul. Indira Gandhi: An Intimate Biography. New York: Pantheon Books, 1992.

Landman, Lynn C. "Birth Control in India: The Carrot and the Rod ." Family Planning Perspectives, 1977: 101-110.

Lewis, Primila. Reason Wounded: An Experience of India's Emergency. Boston: George, Allen \& Unwin, 1979.

Off Our Backs. "Sterilization: No Choice in India." Off Our Backs, 1976: 10.

Tarlo, Emma. Unsettling Memories: Narratives of the Emergency in Delhi. Los Angeles: University of California Press, 2003.

Williams, Rebecca J. "Storming the Citadels of Poverty: Family Planning under the Emergency in India, 1975-1977." The Journal of Asian Studies, 2014: 471-492. 